\title{
A Comparison between Microscopic and Molecular Methods for Identification of Ostreopsis Species in Marine Samples
}

\author{
Antonella Giorgio $^{1,2}$, Anna Montanino ${ }^{3 *}$, Maria Grazia Aquila ${ }^{4}$, Beatrice Cocozziello $^{5}$, Marco Guida ${ }^{6}$
}

${ }^{1,6}$ Department of Biology, University of Naples Federico II, Naples (Italy)

2,3,4,5Provincial Department of Naples, Regional Agency for Environmental Protection of Campania, Naples (Italy)

Received: March 26, 2018; Accepted: April 12, 2018; Published: May 30, 2018

*Corresponding author: Anna Montanino, Provincial Department of Naples, Regional Agency for Environmental Protection of Campania, Naples (Italy), Via Don Bosco, 4/F, Tel: +39 3384858135; E-mail: a.montanino@arpacampania.it

\begin{abstract}
An assessment of $O$. ovata and $O$. cf. siamensis presence in some seawater samples and on macro algae was carried out in the Mediterranean Sea. The identification of taxa investigated was performed using traditional microscopic techniques and molecular tools, to evaluate the distribution area of these species too. Ostreopsis includes epiphytic/benthonic microalgae known for their production of toxic compounds that can cause biopoisoning. Microscopic analysis reveal that the presence of Ostreopsis spp. and $O$. ovata in macroalgal samples is greater than in water ones. In a greater number of samples, through molecular analysis the presence of investigated species has been detected, in comparison to the previous results of microscopic analysis. They also allowed identifying Ostreopsis spp and $O$. ovata species even in those samples in which microscopic analysis hasn't detected any cells, probably because it's beneath the detection limit of method. However for environmental monitoring the microscopic analysis have proved useful to detect the presence with high-precision of these species in a marine environment and to monitor their proliferation in time while molecular approach could be expensive, difficult to apply and inaccurate first of all because of the impossibility to distinguish live cells from dead cells.
\end{abstract}

Keywords: Harmful; Microscopy; PCR; Monitoring;

\section{Introduction}

Ostreopsis includes epiphytic/benthonic microalgae mainly located in shallow waters, characterized by low hydrodynamism. The organisms belonging to Ostreopsis colonize benthonic substrata, like rocks, pebbles, macroalgae, and angiosperms, and also can be found in plankton. This genus includes nine species from tropical and subtropical areas. Among these, Ostreopsis ovata and Ostreopsis cf. siamensis have to be considered foreign and non-indigenous species in the Mediterranean Sea, led there by maritime traffic and spread because of the tropicalization even in temperate areas, in particular in the Adriatic Sea, the
Tyrrhenian Sea, the Ligurian Sea, in Lebanon and along NorthAfrican coasts $[1,6,7,13,20,21,24,27]$. In Italy, Ostreopsis ovata is a wide spread specie, while $O$. cf. siamensis, until now, has been reported only in Sicily [19]. Auspicious environmental causes (hydrodynamic conditions, water temperature, depth and type of substratum) give life to Harmful Algal Blooms (HABs), identified by a brownish mucilaginous film on growth substrata, floating clumps and lathers, in column and on surface, due to the detachment of groups of cells in case of waving motion or mechanical actions $[22,24,16]$. Species belonging to Ostreopsis are known for their productions of Palytoxin-like compounds or PLTX [18]. In addition, O. ovata produces various Palytoxin co-genuses, like Ovatoxins - OVTXs [10]. Inhaling and ingesting these compounds can cause biopoisoning, parainfluenzal and not lethal for human beings, harmful or lethal for marine benthic communities $[4,8,9]$. The symptoms of human poisoning are: fever, labored breathing, bronchoconstriction, conjunctivitis, skin irritation, paraesthesia, itching, dysphagia, asthenia, convulsions and rash. So it is necessary to detect the presence of these species in a marine environment and to monitor their proliferation in time, in order to protect public health and the well-being of the marine ecosystem. Furthermore, the spread of HABs, in particular times of the year, could have an impact on tourism and business activities (like fishing, for example), and lead to negative consequences for business. The identification of various species belonging to Ostreopsis is based on a microscopic observation of the morphological characteristics, sometimes could be very difficult and laborious but lead to an accuracy analytical result. $O$. ovata is different from 0 . cf. siamensis for its smaller dimension, ovoid shape and the dorsoventral/anteroposterior diameter ratio [3]. However many intraspecific variations have been recorded, like the 0 . ovata strain in the Adriatic Sea, which, according to a microscopic observation, seems to have a more flattered shape than the Mediterranean one [15,2]. This is the reason why, in the last few years, molecular biology techniques may help the 
identification and the distinction among different species of Ostreopsis, in order to have a more reliable and immediate result. In particular, these molecular biology techniques are based on the analysis of variations of ITS and 5.8S rDNA regions [17]. These are extremely sensitive techniques, so it's possible to observe the presence of cells, even in case of low concentration. Working on this project here introduced lead to an assessment of $O$. ovata and $O$. cf. siamensis presence in some seawater samples and on macro algae in the Mediterranean Sea, while using traditional microscopic techniques and molecular tools, in order to evaluate the distribution area of these species.

\section{Materials and methods}

\section{Sampling protocol}

Sampling was carried out during 2016, from July to October, at different stations along Campania Coast. A total of 48 samples of macro algae and adjacent seawater were analyzed. All samples were collected at a depth of $0.5 \mathrm{~m}$. 24 macro algae samples were collected, following the "Classical Method" proposed by The Italian National Institute for Environmental Protection and Research - ISPRA [14]. Macroalgae were covered with plastic bag and thallus was cutted at the base with a scalpel or a blade. Materials (5-10 g) were immediately closed into the bag in order to limit cells lost. Once the samples has been collected, they were poured into 1 liter plastic bottles and stored at $4{ }^{\circ} \mathrm{C}$ and dark condition until laboratory analysis (within 6-8 hours). 24 surface seawater samples were obtained according to Protocol of ISPRA 2012, using $500 \mathrm{~mL}$ bottles at the same depth as macro algal thallus, and about $20-30 \mathrm{~cm}$ along, avoiding re suspension of sediments. Water samples were immediately preserved with Lugol's solution ( $2 \mathrm{~mL}$ for $500 \mathrm{~mL}$, Carlo Erba) and stored at $4{ }^{\circ} \mathrm{C}$ until microscopic and molecular analysis.

\section{Microscopic analysis and quantification assay}

Microscopic analysis was performed both on macro algal and water samples. For quantification of $O$. ovata and $O$. cf. siamensis in seawater samples the UNI EN ISO 15204:2006 was adopted. Samples have been manually homogenized using horizontal and vertical rotations for 100 times. Subsamples of $50 \mathrm{~mL}$ were placed in settling chambers and analyzed within 18-24 hours. For quantitative analysis an optical inverted microscope (Zeiss, Axiovert 200) equipped with micro camera, was required.
Quantitative analysis was performed by counting cells in 2 transects, whole chamber or random fields, depending on sample cell density, from 100 to $400 \mathrm{X}$ magnification. The identification of taxa has been required standardized taxonomic literature [23,5]. Abundance of three species investigated was expressed as numbers of cells per liter. Macro algal samples were analyzed according to Protocol of ISPRA 2012. In order to allow dislodgement of epiphytic cells, macro algae samples were vigorously shaken for 2 minutes until the complete removal of cells. Fresh weight was measured after lightly blotting with tissue paper. The collected waters were then recovered in a beaker and macro algal rinsed three times with filtered sea water $(0.45 \mu \mathrm{m})$. Washing seawater has been recovered together with collected water to form samples to analyze. A subsample of each fraction (ca $50 \mathrm{~mL}$ ) was immediately placed on ice and then stored at $-20^{\circ} \mathrm{C}$ for molecular analysis. $250 \mathrm{~mL}$ was preserved with $1 \mathrm{~mL}$ of Lugol's solution and analyzed following Utermöhl Technique (UNI EN ISO 15204:2006) previously described.

Results were expressed as number of cell per $g$ of fresh weight macroalgae (fw) using following formula: cell / $g=$ [(c_count $x \mathrm{~F}$ x vol_fin)/ vol_sed] / fw where 1- c_count correspond to counted cells; $2-\mathrm{F}$ was the ratio chamber area/analyzed area $(\mathrm{F}=1$ if whole chamber has been observed); 3-vol_fin was the final volume of samples (mL); 4- vol_sed correspond to sediment sample volume (mL); 5- fw was the Fresh Weight of thalli (g).

\section{Molecular analysis}

$10 \mathrm{~mL}$ of seawater samples and $50 \mathrm{~mL}$ of macroalgae subsamples, obtained as above, were used for genomic DNA extraction according to procedure of Doyle \& Doyle (1987). Both samples were centrifuged at $10000 \mathrm{rpm}$ for 10 minutes and the pellets used for extraction.

Purity and quality of extracted DNA was analyzed on a $0.8 \%$ agarose gel with $0.5 \%$ TAE Buffer, stained with GelRed (GelRed Nucleic Acid Gel Stain, Biotium). DNA quantification was performed with spectrophotometer NanoDrop 2000 (Thermo Fisher Scientific). PCR amplification was carried out using three sets of primers (Table 1) specific for the ITS-5.8S rDNA regions of genus and species Ostreopsis used in this study [18].

Table 1: Primers sets used for molecular assays, listed according to each target taxa.

\begin{tabular}{|c|c|c|c|c|c|}
\hline \multicolumn{2}{|c|}{ Primer set } & \multirow{2}{*}{$\begin{array}{c}\text { Primer } \\
\text { Ostreopsis F }\end{array}$} & \multirow{2}{*}{$\begin{array}{c}\text { Sequence } \mathbf{5}^{\prime} \rightarrow \mathbf{3}^{\prime} \\
\text { AAAACGATATGAAGAGTGCAGC }\end{array}$} & \multirow{3}{*}{$\begin{array}{c}\text { Target taxa } \\
\text { Ostreopsis spp. }\end{array}$} & \multirow{2}{*}{$\begin{array}{c}\text { Expected size of PCR product (bp) } \\
92\end{array}$} \\
\hline 1 & Forward & & & & \\
\hline & Reverse & Ostreopsis R & CCAGGAGTATGCCTACATTCAA & & \\
\hline \multirow[t]{2}{*}{2} & Forward & Ovata F & CAATGCTCATGTCAATGATG & \multirow[t]{2}{*}{ O. ovata } & \multirow[t]{2}{*}{210} \\
\hline & Reverse & Ostreopsis R & CCAGGAGTATGCCTACATTCAA & & \\
\hline \multirow[t]{2}{*}{3} & Forward & Siamensis F & TGTTACCATTGCTGAGTTTG & \multirow[t]{2}{*}{ O.cf. siamensis } & \multirow[t]{2}{*}{223} \\
\hline & Reverse & Ostreopsis R & CCAGGAGTATGCCTACATTCAA & & \\
\hline
\end{tabular}


Each PCR reaction was prepared in quadruplicate using a different amount of DNA (5ng, 100pg, 10pg and 5pg) in order to assess the sensitivity of procedure. For positive control were used a plasmidic DNA containing the ITS-5.8S rDNA insert of each genus and species tested. For negative control an environmental samples without Ostreopsis cells was chosen. Reactions were set up in a Prime Thermal Cycler (Techne) in a total volume of $50 \mu \mathrm{L}$ containing $5 \mu \mathrm{L}$ of $10 \mathrm{X}$ Reaction Buffer, $1.5 \mathrm{mM} \mathrm{MgCl} 2,0.2 \mathrm{mM}$ of each dNTP, $0.2 \mu \mathrm{M}$ of each primer and $2 \mathrm{U}$ of Taq DNA Polymerase (VWR Chemicals, Taq DNA Polymerase). The PCR amplifications were performed as following: initial denaturation step of $5 \mathrm{~min}$ at $95^{\circ} \mathrm{C}, 30$ cycles of $30 \mathrm{~s}$ at $95^{\circ} \mathrm{C}, 30 \mathrm{~s}$ at $55^{\circ} \mathrm{C}$ and $45 \mathrm{~s}$ at $72^{\circ} \mathrm{C}$, and a final extension step of $5 \mathrm{~min}$ at $72^{\circ} \mathrm{C}$.

An aliquot $(4 \mu \mathrm{L})$ of PCR products were analyzed by electrophoresis in $2 \%$ agarose gel at a voltage of $70 \mathrm{~V}$ for 1 hour. Gel were stained with GelRed (GelRed Nucleic Acid Gel Stain, Biotium) and visualized under UV illuminator, using a 100 bp DNA ladder (DNA Molecular Weight ladders, Amresco) as size marker. PCR products were purified using the QIAquick PCR Purification Kit - Qiagen and used as templates in sequencing reaction with the Big Dye Terminator V3.1 (Applied Biosystems) following manufacturer procedure. Sequencing was performed using an ABI Prism 3100 (Applied Biosystem) and sequences analyzed with Chromas Lite software, version 2.1.1. (Chromas Lite version 2.1, Technelysium; http://technelysium.com.au/?page_id=13) and submitted for Blast analysis to taxonomic affiliation.

\section{Results}

A total of 48 macroalgal samples and of surface seawater were collected and analyzed during period investigated. Microscopic analysis was performed using inverted microscope at 200 and 400X magnification (Figure 1). According to [12], distinctive features for microscopic identification of Ostreopsis members are 1- shape that is anterior-posteriorly compressed, 2- apex that is moved on the dorsal surface on the left side, 3cingulum not descending and 4- epitheca not noticeably smaller than hypotheca in apical view. O. ovata cells, observed under the inverted microscope had drop-shaped body and smallest size as compared with other members of genus. In samples analyzed dorsoventral diameter of cells range from 47 to $57 \mu \mathrm{m}$ while transdiameter range from 23 to $36 \mu \mathrm{m}$. Thecal surface is smooth and ornamented with minute, evenly distributed pores.
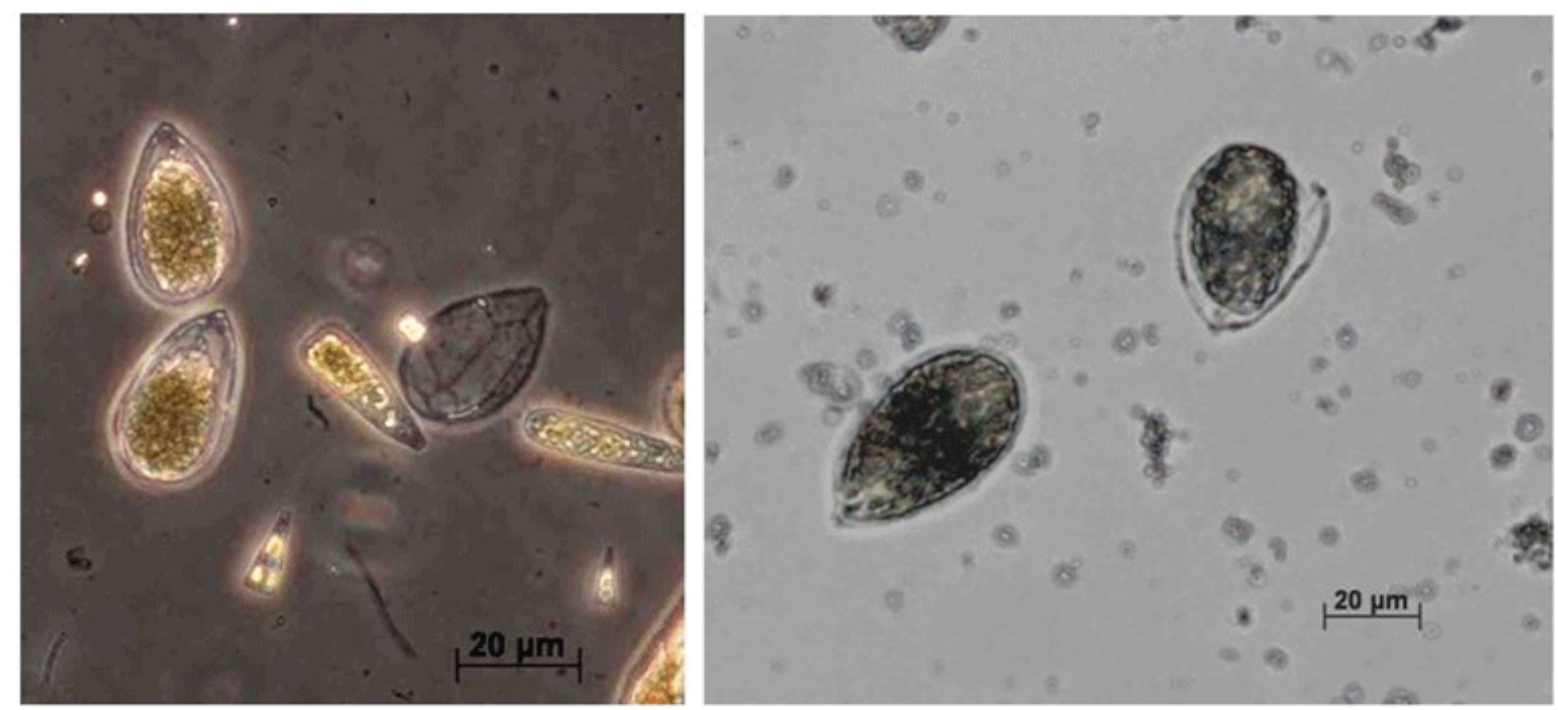

Figure 1: Light micrographs of natural samples investigated.

Microscopic and molecular results, as well as quantitative data were summarized in (Tables 2 and 3 ).

In the seawater samples abundance of Ostreopsis spp. ranged from 0 cells $\mathrm{L}^{-1}$ in samples 1 -W, 2_W, 13_W, 14_W, 15_W, 16_W, 19_W, 20_W, 21_W, 22_W, 23_W and 24_W, to a maximum of 8360 cells $\mathrm{L}^{-1}$ in sample 3_W. The lowest values detected have been 40 cells $\mathrm{L}^{-1}$ in sample 10_W. No cells of 0 . ovata were found in seawater samples, expect for 7_W, 8_W and 18_W. The highest and lowest values recorded were 2180 cell $\mathrm{L}^{-1}$ in sample 8_W and 180 cell $\mathrm{L}^{-1}$ in sample 18 -W. About $50 \%$ seawater samples were positive for Ostreopsis spp. while 0 . ovata were found in $12,5 \%$ of the water samples analyzed. For macroalgal samples $87,5 \%$ and
$66 \%$ were showing positive to Ostreopsis spp. and O. ovata.

Concentration of Ostreopsis spp. in macroalgal samples ranged from 0 cells $~^{-1}$ in 13_M, 16_M and 19_M to a maximum of 109493 cells $\mathrm{g}^{-1}$ in 4_M. The lowest value was 38 cells $\mathrm{g}^{-1}$, observed in sample 20_M. Abundance of 0 . ovata ranged from 0 cells $\mathrm{g}^{-1}$ in samples 6_M, 11_M, 12_M, 15_M, 16_M, 17_M, 19_M and 22_M to a maximum of 66719 cells g $^{-1}$ in sample 8_M. The lowest value was 42 cells $\mathrm{g}^{-1}$ in sample 2_M.

PCR assay was carried out in order to detect target taxa in samples analyzed. 
Table 2: Microscopic and molecular results of seawater samples In table: n.d. not detectable; +/- positive/negative amplification of taxa investigated.

\begin{tabular}{|c|c|c|c|c|c|c|c|}
\hline \multirow[b]{2}{*}{ Sample Number } & \multirow[b]{2}{*}{ Sampling Period } & \multicolumn{3}{|c|}{ Microscopic Results (cells/L) } & \multicolumn{3}{|c|}{ Molecular Results (+/-) } \\
\hline & & $\begin{array}{l}\text { Ostreopsis } \\
\text { spp. }\end{array}$ & $\begin{array}{c}\text { Ostreopsis } \\
\text { ovata }\end{array}$ & $\begin{array}{c}\text { O.cf. } \\
\text { siamensis }\end{array}$ & $\begin{array}{l}\text { Ostreopsis } \\
\text { spp. }\end{array}$ & $\begin{array}{c}\text { Ostreopsis } \\
\text { ovata }\end{array}$ & $\begin{array}{c}\text { O. cf. } \\
\text { siamensis }\end{array}$ \\
\hline 1_W & July & n.d. & n.d. & n.d. & + & - & - \\
\hline 2_W & July & n.d. & n.d. & n.d. & + & - & - \\
\hline 3_W & July & 8360 & n.d. & n.d. & + & - & - \\
\hline 4_W & July & 7820 & n.d. & n.d. & + & - & - \\
\hline 5_W & July & 2140 & n.d. & n.d. & + & - & - \\
\hline 6_W & July & 1260 & n.d. & n.d. & + & - & - \\
\hline 7_W & July & 2180 & 980 & n.d. & + & + & - \\
\hline 8_W & August & 2580 & 2180 & n.d. & + & + & - \\
\hline 9_W & August & 3440 & n.d. & n.d. & + & - & - \\
\hline 10_W & August & 40 & n.d. & n.d. & + & - & - \\
\hline 11_W & August & 100 & n.d. & n.d. & + & - & - \\
\hline 12 WW & August & 200 & n.d. & n.d. & + & - & - \\
\hline 13_W & August & n.d. & n.d. & n.d. & - & - & - \\
\hline $14 \_W$ & August & n.d. & n.d. & n.d. & + & - & - \\
\hline 15_W & September & n.d. & n.d. & n.d. & + & - & - \\
\hline 16_W & September & n.d. & n.d. & n.d. & - & - & - \\
\hline 17_W & September & 3040 & n.d. & n.d. & + & + & - \\
\hline 18_W & September & 520 & 180 & n.d. & + & + & - \\
\hline 19_W & September & n.d. & n.d. & n.d. & + & - & - \\
\hline 20_W & September & n.d. & n.d. & n.d. & - & - & - \\
\hline 21_W & September & n.d. & n.d. & n.d. & + & + & - \\
\hline $22 \_W$ & October & n.d. & n.d. & n.d. & + & - & - \\
\hline 23_W & October & n.d. & n.d. & n.d. & + & - & - \\
\hline 24_W & October & n.d. & n.d. & n.d. & + & - & - \\
\hline
\end{tabular}

Table 3: Microscopic and molecular results of macroalgal samples In table: n.d. not detectable; +/-positive/negative amplification of taxa investigated.

\begin{tabular}{|c|c|c|c|c|c|c|c|}
\hline \multirow[b]{2}{*}{ Sample Number } & \multirow[b]{2}{*}{ Sampling Period } & \multicolumn{3}{|c|}{ Microscopic Results (cells/L) } & \multicolumn{3}{|c|}{ Molecular Results (+/-) } \\
\hline & & Ostreopsis spp. & $\begin{array}{c}\text { Ostreopsis } \\
\text { ovata }\end{array}$ & $\begin{array}{c}\text { O. cf. } \\
\text { siamensis }\end{array}$ & $\begin{array}{l}\text { Ostreopsis } \\
\text { spp. }\end{array}$ & $\begin{array}{c}\text { Ostreopsis } \\
\text { ovata }\end{array}$ & $\begin{array}{c}\text { O. cf. } \\
\text { siamensis }\end{array}$ \\
\hline 1_M & July & 1947 & 127 & n.d. & + & + & - \\
\hline 2_M & July & 622 & 42 & n.d. & + & + & - \\
\hline 3_M & July & 71031 & 65684 & n.d. & + & + & - \\
\hline 4_M & July & 109493 & 63729 & n.d. & + & + & - \\
\hline 5_M & July & 11755 & 27487 & n.d. & + & + & - \\
\hline 6_M & July & 18236 & n.d. & n.d. & + & - & - \\
\hline 7_M & July & 65269 & 48429 & n.d. & + & + & - \\
\hline 8_M & August & 74219 & 66719 & n.d. & + & + & - \\
\hline 9_M & August & 58594 & 5771 & n.d. & + & + & - \\
\hline 10_M & August & 5932 & 641 & n.d. & + & + & - \\
\hline 11_M & August & 4119 & n.d. & n.d. & + & - & - \\
\hline 12_M & August & 2907 & n.d. & n.d. & + & - & - \\
\hline
\end{tabular}




\begin{tabular}{|c|c|c|c|c|c|c|c|}
\hline 13_M & August & n.d. & 70 & n.d. & + & + & - \\
\hline 14_M & August & 1686 & 2490 & n.d. & + & + & - \\
\hline 15_M & September & 1984 & n.d. & n.d. & + & - & - \\
\hline 16_M & September & n.d. & n.d. & n.d. & + & - & - \\
\hline 17_M & September & 9083 & n.d. & n.d. & + & - & - \\
\hline 18_M & September & 3463 & 11421 & n.d. & + & + & - \\
\hline 19_M & September & n.d. & n.d. & n.d. & + & - & - \\
\hline 20_M & September & 38 & 107 & n.d. & + & + & - \\
\hline 21_M & September & 12977 & 21806 & n.d. & + & + & - \\
\hline 22_M & October & 689 & n.d. & n.d. & + & - & - \\
\hline 23_M & October & 2861 & 10758 & n.d. & + & + & - \\
\hline 24_M & October & 21306 & 17565 & n.d. & + & + & - \\
\hline
\end{tabular}

The size of PCR products expected were as follows: $92 \mathrm{bp}$ for Ostreospis spp., $210 \mathrm{bp}$ for O. ovata e $223 \mathrm{bp}$ O. cf. siamensis. Amplification reaction gives positive results to all DNA concentration tested. Molecular results revealed the presence of Ostreopsis spp. and O. ovata in samples even when target species were not detected by microscopy analysis. Overall $87,5 \%$ and $20 \%$ of seawater samples were positive to Ostreopsis spp. and 0 . ovata. PCR amplification was positive in $100 \%$ and $66 \%$ macroalgal samples for Ostreopsis spp. and O. ovata. No samples were found to be positive to $O$. cf. siamensis, by using microscopic and molecular analysis.

\section{Discussion}

The main aim of the study here proposed has been the comparison between traditional microscopic techniques and molecular methods in order to detect the presence of Ostreopsis and toxic $O$. ovata and $O$. cf. siamensis species in water and in macroalgal samples. Microscopic analysis reveal that the presence of Ostreopsis spp. and O. ovata in macroalgal samples is greater than in water ones. Ostreopsis spp. and O. ovata have been identified in 21 and 16 macroalgal samples, and in 12 and 3 water samples. Furthermore, it has been detected that each positive water sampling matches a positive macroalgal samples, but not the other way around. In a greater number of samples, through molecular analysis the presence of investigated species has been detected, in comparison to the previous results of microscopic analysis. They also allowed to identify Ostreopsis spp. and O. ovata species even in those samples in which microscopic analysis hasn't detected any cells, probably because it's beneath the detection limit of method (for example 13_M, 16_M and 19_M). Ostreopsis spp. has been found in all macroalgal samples and in 21 water samples, while 0 . ovata has been identified respectively in 16 macroalgal and in 5 water samples. The results of the two analyses don't correspond for the research of Ostreopsis spp. in 15 water samples: (1_W, 2_W, 14_W, 15_W, 19_W, 21_W, 22_W, 23_W and 24_W). These results emphasize the difficulty of detecting the presence of Ostreopsis when in low concentration or under detection limit. In fact, the greater divergence between the different data obtained using the two methods are more evident in water samples than in macroalgal samples. In fact, they are mainly benthonic species, so the concentrations detected in water columns are always low, excepted for bloom events. For example, in 1_W, 2_W, 19_W, 21_W, 22_W, 23_W and 24_W samples microscopic analysis hasn't revealed any investigated taxa. Molecular analysis, instead, have revealed the presence of Ostreopsis spp. in each samples and also of 0 . ovata in 21_W samples. None of the two methods has revealed the presence of $O$. cf. siamensis, as a proof that the distribution area is now confined in the western Mediterranean Sea.

After all, the study reveals that: 1-as the microscopic techniques was validated could be obtained a high-quality result. The calibration of method makes possible to prevent error related to critical phases that could invalidate the result of the analysis such as: homogenization, sedimentation, distribution of cells in the sedimentation area, the repeatability and the reproducibility of data; 2- the microscopic method required high-resolution equipment and updated taxonomical books. The analysts should be well-prepared to use microscopic techniques and have a good knowledge of taxonomy; they should be highly trained and up to date, because of highly intraspecific diversity due to the geographical variables for the researched species; 3-molecular biology techniques have been useful to identify 0 . ovata cells in natural samples, where there are other phytoplankton species. They are also very fast and safe. The use of commercially available kits allows to extract the genomic DNA in a few hours and to verify the result of the PCR amplification in a very short time. The main disadvantages of the molecular methods are the price of reagent and equipment as well as the absence of validated official methods. Furthermore molecular techniques don' $t$ allow the detection of live cells from dead ones so they can lead to an inaccurate result; 4-the reliability of data obtained from the molecular analysis is due to the usage of genus-specific and species-specific primer, which have no similarities with DNA regions belonging to different genus and species. Fast and reliable revelation methods are particularly important for environmental monitoring, in order to detect any critical case and potential risk 
due to the presence of toxic species. Nevertheless, in order to individuate algal bloom and to answer the specific requests of monitoring program the microscopic analysis allows obtaining an accurate quantification of harmful species, unlike the molecular methods used.

\section{Conflict of Interest}

The authors declare that they have no conflict of interest.

\section{References}

1. Accoroni S, Romagnoli T, Colombo F, Pennesi C, Di Camillo $\mathrm{CG}$, Marini $\mathrm{M}$, et al. Ostreopsis cf. ovata bloom in the northern Adriatic Sea during summer 2009: ecology, molecular characterization and toxin profile. Marine Pollution Bulletin. 2011;62(11):2512-2519.

2. Accoroni S, Romagnoli T, Pichierri S, Colombo F, Totti C. Morphometric analysis of Ostreopsis cf. ovata cells in relation to environmental conditions and bloom phases. Harmful Algae. 2012;19:15-22.

3. Accoroni S, Totti C. The toxic benthic dinoflagellates of the genus Ostreopsis in temperate areas: a review. Advances in Oceanography and Limnology. 2016;7(1):1-15.

4. Aligizaki K, Katikou P, Nikolaidis G, Panou A. First episode of shellfish contamination by palytoxin-like compounds from Ostreopsis species (Aegean Sea, Greece). Toxicon. 2008;51(3):418-427.

5. Avancini M, Cicero AM, Di Girolamo I, Innamorati M, Magaletti E, Zunini TS. Guida al riconoscimento del plancton dei mari italiani. Vol. I Fitoplancton. Programma di monitoraggio per il controllo dell'ambiente marino costiero. Ministero dell'Ambiente e della Tutela del Territorio e del Mare. ICRAM. 2006.

6. Bushati M, Koni E, Miho A, Bregaj M. Temporal distribution of potentially toxic algae (dinoflagellates and diatoms) in butrinti lagoon. Natura Montenegrina. 2010;9(3):307-319.

7. Carnicer O, García-Altares M, Andree KB, Diogene J, Fernández-Tejedor M. First evidence of Ostreopsis cf. ovata in the eastern tropical Pacific Ocean, Ecuadorian coast. Botanica Marina. 2016;59(4):267-274.

8. Casabianca S, Casabianca A, Riobó P, Franco JM, Vila M, Penna A. Quantification of the toxic dinoflagellate Ostreopsis spp. by qPCR assay in marine aerosol. Journal of Environmental Science and Technology. 2013;47(8):37883795.

9. Ciminiello P, Dell'Aversano C, Dello Iacovo E, Fattorusso E, Forino M, Tartaglione L, et al. First finding of Ostreopsis cf. Ovata toxins in marine Aerosols. Environmental Science \& Technology. 2014;48(6):3532-3540.

10. Ciminiello P, Dell'Aversano C, Dello Iacovo E, Fattorusso
E, Forino M, Tartaglione $\mathrm{L}$, et al. Unique toxin profile of a Mediterranean Ostreopsis cf. ovata Strain: HR LC-MS(n) characterization of Ovatoxin-f, a new palytoxin congener. Chemical Research in Toxicology. 2012;25(6):1243-1252.

11. Doyle JJ, Doyle JL. A rapid DNA isolation procedure from small quantities of fresh leaf tissue. Phytochemical Analysis. 1987;19:11-15.

12. Faust MA, Morton SL, Quod JP. Further SEM study of marine dinoflagellates: The genus Ostreopsis (Dinophyceae). Journal of Phycology. 1996;32(6):1053-1065.

13. Ismael A, Halim Y. Potentially harmful Ostreopsis spp. in the coastal waters of Alexandria-Egypt. Mediterranean Marine Science. 2012;13(2):208-212.

14. ISPRA, Quaderni - Ricerca Marina n. 5/2012. Monitoraggio di Ostreopsis ovata e Ostreopsis spp.: protocolli operativi. ISBN 978-88-448-05586.

15. Monti M, Minocci M, Beran A, Ivesa L. First record of Ostreopsis cfr. Ovata on macroalgae in the Northern Adriatic Sea. Marine Pollution Bulletin. 2007;54(5):598601.

16. Nascimento SM, França JV, Gonçalves JEA, Ferreira CEL. Ostreopsis cf. ovata (Dinophyta) bloom in an equatorial island of the Atlantic Ocean. Marine Pollution Bulletin. 2012;64(5):1074-1078.

17. Penna A, Battocchi C, Capellacci S, Fraga S, Aligizaki K, Lemée $\mathrm{R}$, et al. Mitochondrial, but not rDNA, genes fail to discriminate dinoflagellate species in the genus Ostreopsis. Harmful Algae. 2014;40:40-50.

18. Penna A, Vila M, Fraga S, Giacobbe MG, Andreoni F, Riobó P, et al. Characterization of Ostreopsis and Coolia (Dinophyceae) isolates in the western Mediterranean Sea based on morphology, toxicity and internal transcribed spacer 5.8s rDNA sequences. Journal of Phycology. 2005;41(1):212-225.

19. Penna A, Fraga $S$, Battocchi $C$, Casabianca $S$, Riobò $P$, Giacobbe MG, et al. A phylogeographical study of the toxic benthic dinoflagellate genus Ostreopsis Schmidt. Journal of Biogeography. 2010;37(5):830-841.

20. Pfannkuchen M, Godrijan J, Marić Pfannkuchen D, Iveša $L$, Kružic P, Ciminiello P, et al. Toxin-producing Ostreopsis cf. ovata are likely to bloom undetected along coastal areas. Environmental Science \& Technology. 2012;46(10):55745582.

21. Sechet V, Sibat M, Chomérat N, Nézan E, Grossel H, Lehebel-Peron JB, et al. Ostreopsis cf. ovata in the French Mediterranean coast: molecular characterization and toxin profile. Cryptogamie, Algologie. 2012;33(2):89-98.

22. Shears NT, Ross PM. Blooms of benthic dinoflagellates 
of the genus Ostreopsis; an increasing and ecologically important phenomenon on temperate reefs in New Zealand and worldwide. Harmful Algae. 2009;8(6):916-925.

23. Hasle GR, Syvertsen EE, Steidinger KA, Tangen K. Dinoflagellates. In: Tomas CR (Ed), Identifying Marine Diatoms and Dinoflagellates, Academic Press, New York. 1996:387-598.

24. Totti C, Accoroni S, Cerino F, Cucchiari E, Romagnoli T. Ostreopsis ovata bloom along the Conero Riviera (northern Adriatic Sea): relationships with environmental conditions and substrata. Harmful Algae. 2010;9(2):233-239.
25. CSN EN 15204 - Water quality - Guidance standard on the enumeration of phytoplankton using inverted microscope - Utermöhl technique. 2006.

26. Utermohl H. Zur Vervollkommnung der quantitativen Phytoplankton-Methodik: Mitt. 1958.

27. Vila M, Arin L, Battocchi C, Bravo I, Fraga S, Penna A, et al. Management of Ostreopsis blooms in recreational waters along the Catalan coast (NW Mediterranean Sea): cooperation between a research project and a monitoring program. Cryptogamie Algologie. 2012;33(2):143-152. 